\title{
PERAMALAN INDEKS PEMBANGUNAN MANUSIA (IPM) KABUPATEN BOJONEGORO MENGGUNAKAN METODE DOUBLE EXPONENTIAL SMOOTHING BROWN
}

\author{
Yuniar Farida ${ }^{1}$, Diah Ayu Sulistiani ${ }^{2}$, Nurissaidah Ulinnuha ${ }^{3}$ \\ 1,2,3 UIN Sunan Ampel, Jl. Ahmad Yani No.117, Wonocolo, Surabaya, Indonesia \\ Email: 1yuniar_farida@uinsby.ac.id
}

\begin{abstract}
Human development is shown as a benchmark for the success of a nation's development, which is closely related to the economic, social, cultural, political, and environment. The success of human development is measured based on Human Development Index (HDI). Bojonegoro regency is one of the regencies in East Java Province, with diverse and abundant natural resources. The magnitude of the potential of natural resources should be in line with the quality of the human resource. However, it turns out that this is not in line with the HDI value of Bojonegoro Regency, which is below the average $\mathrm{HDI}$ value of East Java. So that the Bojonegoro government continues to maximize the potential and increase the $\mathrm{HDI}$ value, it is necessary to do forecasting to optimize the level of human development in the Bojonegoro regency in the next few years. This study predicts HDI in Bojonegoro regency using Double Exponential Smoothing (DES) method from Brown, with the data used being HDI data in Bojonegoro Regency from 2010 to 2020. The data used were obtained from the Regional Development Planning Agency (Bappeda) and Statistic Center (BPS) of Bojonegoro regency. Based on the calculation results, the best forecast is obtained based on the parameter value a 0.7 with a MAPE value of $0.376 \%$, which is included in the excellent criteria, the HDI forecasting results for 2021 are 69.61 , for 2022 it is 70.14 , and for 2023 it is 70.67, which had in the medium HDI category.
\end{abstract}

Keywords: Double exponential smoothing brown, Human Development Index (HDI), forecasting

\begin{abstract}
ABSTRAK
Pembangunan manusia kini dipandang sebagai tolak ukur keberhasilan pembangunan suatu bangsa yang berkaitan erat dengan bidang ekonomi, sosial, budaya, politik, dan lingkungan. Keberhasilan pembangunan manusia diukur berdasarkan Indeks Pembangunan Manusia (IPM). Kabupaten Bojonegoro merupakan salah satu kabupaten di Provinsi Jawa Timur yang mempunyai sumber daya alam yang beragam dan melimpah. Besarnya potensi sumber daya alam yang dimiliki seharusnya sejalan dengan kualitas pembangunan manusianya. Namun ternyata hal tersebut tidak sejalan dengan nilai IPM Kabupaten Bojonegoro yang berada di bawah rata-rata nilai IPM Jawa Timur. Sehingga pemerintah Bojonegoro terus berupaya untuk memaksimalkan potensi dan meningkatkan nilai IPM. Berdasarkan hal tersebut maka perlu dilakukan peramalan (forecasting) sebagai acuan untuk memaksimalkan tingkat pembangunan manusia di Kabupaten Bojonegoro pada beberapa tahun yang akan datang. Pada penelitian ini, untuk meramalkan IPM di Kabupaten Bojonegoro menggunakan metode Double Exponential Smoothing (DES) dari Brown dengan data yang digunakan merupakan data IPM di Kabupaten Bojonegoro dari tahun 2010 sampai 2020. Data yang digunakan diperoleh dari Badan Perencanaan Pembangunan Daerah (Bappeda) dan Badan Pusat Statistik (BPS) Kabupaten Bojonegoro. Berdasarkan hasil perhitungan, peramalan terbaik diperoleh berdasarkan nilai parameter a 0.7 dengan besar nilai MAPE 0.376\% yang masuk kriteria sangat baik. Hasil peramalan IPM untuk tahun 2021 sebesar 69.61, untuk tahun 2022 sebesar 70.14, dan untuk tahun 2023 sebesar 70.67 termasuk kategori IPM sedang.
\end{abstract}

Kata kunci: Double exponential smoothing brown, Indeks Pembangunan Manusia (IPM), peramalan

Dikirim: 25 Juni 2021; Diterima: 31 Agustus 2021; Dipublikasikan: 30 September 2021

Cara sitasi: Farida, Y., Sulistiani, D. A., \& Ulinnuha, N. (2021). Forecasting indeks pembangunan manusia di kabupaten bojonegoro menggunakan metode double exponential smoothing brown. Teorema: Teori dan Riset Matematika, 6(2), 173-183. DOI: $\underline{\text { http://dx.doi.org/10.25157/teorema.v6i2.5521 }}$ 


\section{PENDAHULUAN}

Pembangunan adalah salah satu sarana yang digunakan suatu bangsa dalam mencapai tujuan nasional, dan tingkat pertumbuhan ekonomi adalah salah satu indikator yang menunjukkan keberhasilan pembangunan dalam suatu negara. Dalam melaksanaan pembangunan suatu negara, tingginya pertumbuhan ekonomi menjadi sasaran utama pada negara yang sedang berkembang seperti negara Indonesia. Paradigma pembangunan yang saat ini sedang berkembang yaitu pertumbuhan ekonomi dengan pembangunan manusia sebagai tolak ukur tingkat kualitas hidup bagi manusia di negara tersebut (Mirza, 2012). Dengan kata lain, dampak antara perekonomian dan pembangunan manusia memiliki keterkaitan, begitu pula sebaliknya dimana dampak perbaikan tingkat kualitas hidup manusia pada jangka panjang dapat berdampak pada peningkatan perekonomian (Winarti, 2014).

Pembangunan manusia adalah suatu konsep yang mendorong peningkatan kualitas hidup manusia secara fisik maupun secara spiritual, yang berdasarkan pembangunan Sumber Daya Manusia, dimana hal tersebut bermakna dengan meningkatkan kapasitas dasar penduduk dalam berpartisipasi pada proses pembangunan berkelanjutan. Kualitas pembangunan manusia yang tinggi menunjukkan kemampuan penduduk dalam berpartisipasi, mengelola, dan menggunakan sumbersumber pertumbuhan ekonomi, pada bidang teknologi maupun kelembagaan dalam mencapai pertumbuhan manusia (Dewi \& Sutrisna, 2012).

Pembangunan manusia bertujuan untuk memperbesar kebebasan manusia, membantu manusia dalam mendapatkan dan menikmati lebih banyak kesempatan dalam menggunakan kemampuan tersebut, sehingga manusia merasakan kehidupan yang layak, berpengetahuan, dan memiliki akses menuju kehidupan yang lebih baik. Pembangunan manusia didukung berdasarkan empat pilar pokok yaitu produktivitas dimana penduduk harus produktif dan berpartisipasi dalam menciptakan pendapatan, pemerataan dimana semua penduduk berkesempatan mendapatkan akses dalam penggunaan sumber daya di bidang ekonomi dan sosial, kesinambungan yaitu pembaharuan terhadap akses sumber daya ekonomi dan sosial, dan pemberdayaan dimana penduduk harus selalu berpartisipasi dalam pengambilan keputusan pada proses pembangunan (Ouedraogo, 2013).

United Nations Development Program (UNDP) memberikan suatu tolak ukur dalam menilai keberhasilan pembangunan manusia yaitu menggunakan Indeks Pembangunan Manusia (IPM) atau Human Development Indeks (HDI). Indeks Pembangunan Manusia (IPM) atau Human Development Index (HDI) pertama kali diperkenalkan tahun 1990 oleh Amartya Sen seorang pemenang nobel dari India dan Mahbub UI Haq seorang ekonom Pakistan, serta dibantu oleh Gustav Ranis dari Yale University dan Lord Merghnad Desai dari London School of Economics. Dimana sejak saat itu, istilah IPM digunakan oleh Program Pembangunan PBB dalam laporan tahunan Human Development Report (HDR) (Ouedraogo, 2013). UNDP menyusun IPM berdasarkan tiga indikator, yaitu pada Indikator Kesehatan yang berdasarkan pada Angka Harapan Hidup (AHH), Indikator Pendidikan berdasarkan pada Angka Harapan Sekolah (AHS) dan Rata-rata Lama Sekolah (RLS), dan Indikator Standar Hidup Layak berdasarkan pada Pengeluaran per Kapita (Setiawan \& Hakim, 2008). Meskipun IPM adalah suatu tolak ukur pembangunan sumber daya manusia yang telah dirumuskan secara konstan, nilai tersebut tidak akan pernah dapat menggambarkan pembangunan sumber daya manusia secara sempurna (Mirza, 2012).

Nilai pada IPM berkisar dari 0 hingga 100, jika nilai IPM semakin besar atau mendekati 100 maka nilai tersebut menunjukan tingkat pembangunan manusia yang lebih baik. Berdasarkan pada nilai IPM, UNDP mengelompokkan tingkat pembangunan pada manusia menjadi empat golongan, yaitu rendah apabila nilai IPM kurang dari 60 , sedang atau menengah jika nilai IPM berkisar dari 60 sampai 70, tinggi jika nilai IPM lebih dari 70, dan sangat tinggi apabila nilai IPM lebih dari 80 . Manfaat IPM dalam kehidupan adalah untuk menegaskan bahwa manusia dan kemampuannya seharusnya menjadi kriteria utama dalam menilai pembangunan suatu negara, untuk menelaah pilihan pengambilan kebijakan di suatu negara, dan untuk memperlihatkan perbedaan antar negara 
sehingga akan muncul diskusi antar negara dalam pengambilan keputusan yang terbaik (Sagar \& Najam, 1998).

Berdasarkan publikasi Badan Pusat Statistik (BPS) nilai IPM Indonesia pada tahun 2010 sebesar 66.53 dan pada saat tahun 2020 IPM Indonesia sebesar 71.94. IPM Indonesia terus mengalami peningkatan setiap tahunnya, namun capaian tersebut masih dibawah target yang direncanakan Presiden yakni 71.98. Meskipun sebenarnya pemerintah tidak menetapkan angka pasti pada target IPM, namun pemerintah menargetkan kenaikan IPM. Pada tahun 2019 IPM Indonesia berada di peringkat 6 ditingkat ASEAN dan peringkat 111 didunia dari 189 negara. Pembangunan manusia di Jawa Timur terus mengalami peningkatan selama sepuluh tahun terakhir. Pada tahun 2010 nilai IPM Jawa Timur sebesar 65.36 dan pada tahun 2020 mencapai angka 71.71. Hal tersebut ditandai dengan peningkatan kategori pada beberapa wilayah. Pemerintah Jawa Timur terus berupaya meningkatkan kinerja pembangunan manusianya supaya tidak terjadi ketimpangan antar wilayah (BPS, 2020).

Kabupaten Bojonegoro dalam Rencana Pembangunan Jangka Menengah Daerah (RPJMD) menempatkan pembangunan manusia berdasarkan dua perspektif yaitu pada IPM dan pada pemenuhan hak dasar manusia yang meliputi 10 dimensi, yaitu pangan, kesehatan, pendidikan, kesempatan kerja dan berusaha, perumahan, air bersih dan sanitasi, tanah, sumber daya alam dan lingkungan hidup, rasa aman, dan partisipasi. Topografi Kabupaten Bojonegoro yang terletak pada alam yang sangat bervariasi sehingga dilimpahi kesuburan tanah, memiliki banyak wilayah perbukitan, dilewati oleh sungai bengawan solo, dan terdapat sumber minyak dibawah tanah yang sangat melimpah menjadikannya kaya sumber daya alam. Produksi hasil pertanian yang melimpah, menjadikan Bojonegoro untuk menyatakan diri sebagai "Lumbung Pangan dan Energi untuk Negeri". Pada wilayah perbukitan dan pegunungan sesuai untuk dijadikan kawasan hutan yang menghasilkan berbagai jenis kayu yang dipasarkan hingga luar wilayah (Bojonegoro, 2013). Perbandingan capaian IPM Kabupaten Bojonegoro dengan capaian IPM rata-rata di Jawa Timur dalam 11 tahun terakhir berdasarkan data dari Bappeda (2020) disajikan dalam Gambar 1.

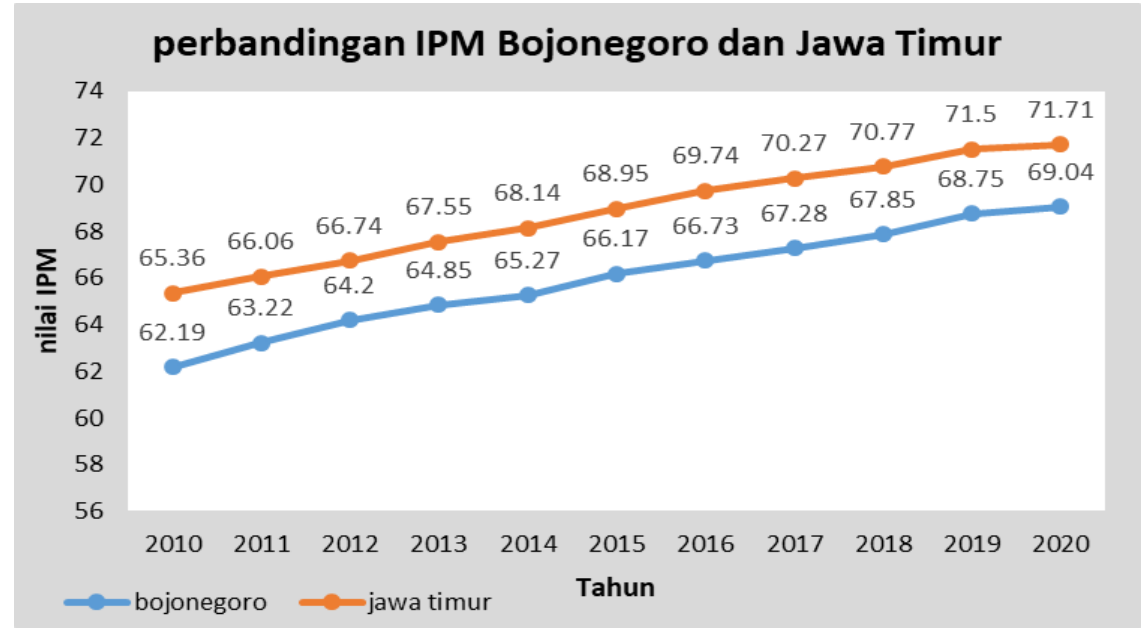

Gambar 1. Perbandingan IPM Bojonegoro dan Jawa Timur

Berdasarkan Gambar 1, terlihat bahwa nilai IPM Kabupaten Bojonegoro masih berada di bawah capaian nilai IPM rata-rata di Jawa Timur, dengan selisih rata-rata sebanyak 2.84 poin dalam 11 tahun terakhir. Nilai IPM Kabupaten Bojonegoro menempati urutan ke 26 dari 38 Kabupaten dan Kota yang berada di Jawa Timur. Padahal Kabupaten Bojonegoro memiliki banyak potensi kekayaan alam yang melimpah dan tentunya diharapkan berkontribusi positif terhadap nilai IPM (BPS, 2020). Menghadapi kondisi tersebut, pemerintah kabupaten terus berupaya memaksimalkan potensi sumber daya yang tersedia dan meningkatkan nilai capaian IPM demi Kabupaten Bojonegoro yang lebih baik kedepannya (Bojonegoro, 2013). Sehingga untuk mengetahui besar peningkatan atau 
penurunan nilai IPM beberapa tahun kedepan, perlu dilakukan peramalan atau prediksi (forecasting) terhadap nilai IPM di Kabupaten Bojonegoro. Hasil prediksi tersebut dapat menjadi acuan pihak pemerintah dalam mengambil kebijakan untuk meningkatkan pembangunan manusia yang lebih baik kedepannya.

Beberapa metode yang digunakan dalam melakukan suatu prediksi (forecasting) diantaranya yaitu metode Backpropagation Neural Network yang merupakan salah satu metode jaringan saraf tiruan (neural network) terawasi yang sering digunakan pada jaringan multi-layer yang terdiri atas beberapa hidden unit, yang bertujuan untuk meminimalkan tingkat kesalahan pada output yang dihasilkan oleh jaringan (Wang et al., 2011), metode Adaptive Neuro Fuzzy Inference System (ANFIS) yang merupakan metode gabungan dari Backpropagation Neural Network dan logika fuzzy, metode ini terdiri dari lima lapisan (layer) yang mendapatkan perlakuan berbeda tiap lapisannya (Ubeyli, 2005), metode Autoregressive Integrated Moving Average (ARIMA) yaitu salah satu metode dalam melakukan peramalan untuk data time series, yang memiliki tiga model yaitu model AR (Autoregresive), model MA (Moving Average), dan model ARMA (Autoregresive and Moving Average) (Zhang, 2003), metode exponential smoothing adalah salah satu metode pada peramalan data time series, yang dilakukan melalui pemulusan nilai data dimasa lalu dengan menguranginya secara eksponensial dan menentukan nilai parameter pemulusan alpha pada setiap data (Hyndman et al., 2002). Dalam menggunakan metode exponential smoothing, pola data yang digunakan harus mengandung pola data trend, yaitu pola data yang terdapat kenaikan atau penurunan pada perluasan periode dalam suatu waktu (Jr, 2003).

Berdasarkan penelitian terdahulu pada peramalan aliran sungai di Sulawesi Selatan yang membandingkan metode exponential smoothing dan ARIMA, diperoleh hasil peramalan terbaik dengan menggunakan metode exponential smoothing dengan nilai MAPE 21.49\% (Lukman \& Tanan, 2021). Selanjutnya penelitian lainnya tentang peramalan harga minyak mentah menggunakan perbandingan antara metode double exponential smoothing Brown dan Holt, diperoleh hasil terbaik dengan menggunakan metode double exponential smoothing Brown dengan a terbaik 0.47206 dan nilai MAPE 13.061\% (Saputra et al., 2017).

Dalam penelitian lain pada peramalan pengurangan jitter dengan membandingkan metode double exponential smoothing, kalman filter (KF) dan extended kalman filter (EKF), diperoleh hasil peramalan terbaik dengan menggunakan metode double exponential smoothing dengan MAPE sebesar 18\% (Gyo \& Kim, 2013). Selanjutnya terdapat penelitian yang membandingkan metode Double Exponential Smooting dengan metode ARIMA dan diperoleh hasil terbaik menggunakan metode Double Exponential Smooting dengan nilai MAPE 7,59\% (Tang et al., 2013). Pada penelitian selanjutnya tentang peramalan permintaan pakaian batik Arini menggunakan metode double exponential smoothing brown diperoleh hasil permintaan sebanyak 10324 pakaian, parameter a terbaik yaitu 0.581 , dan nilai MAPE $15.368 \%$ (Jahring \& Pradani, 2016).

Berdasarkan plot data nilai IPM Kabupaten Bojonegoro pada Gambar 1, terlihat bahwa nilai datanya mengandung trend dimana setiap tahun mengalami kenaikan (trend kenaikan). Sehingga metode peramalan yang dipertimbangkan untuk digunakan pada penelitian ini yaitu metode exponential smoothing. Berdasarkan beberapa penelitian sebelumnya yang melakukan peramalan (forecasting) menggunakan metode double exponential smoothing dan mendapatkan hasil peramalan yang baik pada data trend, maka pada penelitian ini menggunakan metode Double Exponential Smoothing (DES). Pada metode double exponential smoothing dibagi menjadi dua jenis, yaitu metode DES satu parameter dari Brown dan DES dua parameter dari Holt (Ismail \& Yeng, 2011). Data yang digunakan dalam penelitian ini hanya satu parameter sebagaimana pada Gambar 1 dimana pola datanya menunjukkan pola data trend kenaikan, maka dipilih metode Double Exponential Smoothing satu parameter dari Brown. Penelitian ini diharapkan dapat membantu untuk memprediksi besar nilai Indeks Pembangunan Manusia (IPM) di Kabupaten Bojonegoro untuk beberapa tahun yang akan datang, sehingga pemerintah Kabupaten Bojonegoro dapat memaksimalkan setiap potensi dan sumber daya yang tersedia untuk meningkatkan kualitas 
pembangunan manusia yang dapat dijadikan dasar penentuan tujuan pembangunan dan memberikan petunjuk mengenai arah kebijakan pembangunan dimasa depan untuk menuju Bojonegoro yang lebih baik.

\section{METODE PENELITIAN}

Penelitian ini menggunakan data IPM Kabupaten Bojonegoro periode tahun 2010-2020, yang bersumber dari data publikasi Badan Perencanaan Pembangunan Daerah (Bappeda) dan Badan Pusat Statistik (BPS) Kabupaten Bojonegoro. Pada penelitian ini, penulis menggunakan metode Double Exponential Smoothing dari Brown dalam melakukan perhitungan peramalan nilai IPM.

Peramalan (Forecasting) merupakan suatu upaya memperkirakan kondisi dimasa mendatang melalui pengujian keadaan dimasa lalu yang secara alamiah berdasarkan pola data atau informasi, dan menggunakan kebijakan yang relevan dimasa lalu (Rana \& Koprinska, 2016). Peramalan digunakan dalam mendapatkan prediksi atau peramalan yang dapat meminimumkan tingkat kesalahan atau error. Dalam melakukan peramalan, lebih banyak menggunakan data time series (deret waktu) sebagai dasar penarikan trend untuk melihat perkembangan suatu data. Hasil dari peramalan digunakan sebagai dasar perencanaan atau penarikan kesimpulan (Liantoni \& Agusti, 2018). Metode smoothing merupakan salah satu teknik dalam peramalan atau forecasting yang mengambil nilai rata-rata dari periode yang akan datang, berdasarkan data historis atau masa lampau.

Metode double exponential smoothing dari Brown adalah suatu model linear yang diperkenalkan oleh Brown, yang lebih tepat digunakan dalam meramalkan data yang mengalami trend kenaikan. Kelebihan metode ini dapat memodelkan trend dengan data yang relatif sedikit dan terbatas. Namun kekurangan metode ini yaitu membutuhkan nilai parameter terbaik, sehingga diperlukan waktu yang relatif lama dalam menemukan nilai a optimal (Hansun, 2016). Dalam metode double exponential smoothing proses pemulusan (smoothing) dilakukan sebanyak dua kali, karena dasar pemikiran metode double exponential smoothing dari Brown sama dengan rata-rata yang bergerak linear. Hal tersebut terjadi karena nilai smoothing tunggal dan ganda tertinggal dari data yang sebenarnya (Syafwan et al., 2021).

Tahapan pada penelitian dalam menentukan peramalan menggunakan metode double exponential smoothing dari Brown adalah: (Muchayan, 2019)

1. Menentukan nilai Single Exponential Smoothing $\left(S_{t}^{t}\right)$

$$
S_{t}^{\prime}=\alpha X_{t}+(1-\alpha) S_{t-1}^{\prime}
$$

2. Menentukan nilai Double Exponential Smoothing $\left(S_{t}^{\prime \prime}\right)$

3. Menentukan nilai konstanta $\left(a_{t}\right)$

$$
S_{t}^{n}=\alpha S_{t}^{\prime}+(1-\alpha) S_{t-1}^{n}
$$

$$
a_{t}=S_{t}^{\prime}+\left(S_{t}^{\prime}-S_{t}^{\prime \prime}\right)=2 S_{t}^{\prime}-S_{t}^{\prime \prime}
$$

4. Menentukan besarnya slope $\left(b_{t}\right)$.

5. Menentukan nilai peramalan atau forecast $\left(f_{t+m}\right)$

$$
b_{t}=\frac{\pi}{1-\alpha}\left(S_{t}^{\prime}-S_{t}^{n}\right)
$$

Keterangan:

$$
f_{t+m}=a_{t}+b_{t}(m)
$$

$$
\begin{array}{ll}
S_{t}^{\prime} & =\text { nilai single exponential smoothing periode ke-t } \\
X_{t} & =\text { nilai aktual periode ke-t } \\
\alpha & =\text { parameter smoothing }(0<\alpha<1) \\
S_{t-1}^{y} \quad=\text { nilai hasil single exponential smoothing sebelumnya } \\
S_{t}^{y} \quad=\text { nilai double exponential smoothing periode ke-t }
\end{array}
$$


$S_{t-1}^{n t} \quad=$ nilai hasil double exponential smoothing sebelumnya

$a_{t} \quad=$ besarnya nilai konstanta dari periode ke-t

$b_{t} \quad=$ besarnya nilai taksiran trend dari data yang sesuai (slope)

$f_{t+m}=$ hasil peramalan atau forecast

$m \quad$ = jumlah periode yang akan diramalkan

Setiap situasi prediksi atau peramalan (forecast) mengandung derajat ketidakpastian, dimana keadaan tersebut menunjukan tingkat ketepatan (error) suatu peramalan. Tingkat ketepatan (error) digunakan sebagai kriteria penolakan dalam menentukan dan memilih metode peramalan (Airlangga et al., 2019). Metode yang paling sering digunakan dalam menentukan tingkat ketepatan adalah Mean Absolute Percentage Error (MAPE). Perhitungan MAPE dilakukan pada setiap periode ke-i atau dalam setiap amatan (Wang et al., 2012). Hasil dari nilai MAPE dapat digunakan dalam mencari nilai $\alpha$ terbaik dengan cara trial and error. $\alpha$ terbaik ditentukan berdasarkan nilai MAPE terkecil. Dalam menentukan parameter a hanya diambil kisaran nilai yang terbatas, meskipun menurut teori nilai parameter a dianggap bernilai antara 0 dan 1 (Fauziah \& Gunaryati, 2017). MAPE secara umum dirumuskan sebagai:

$$
\text { MAPE }=\frac{\sum_{i=1}^{n}\left|\frac{X_{i}-F_{i}}{X_{i}}\right|}{n} \times 100 \%
$$

Keterangan:

$$
\begin{aligned}
& X_{i}=\text { nilai data riil hasil amatan ke-i } \\
& F_{i}=\text { nilai ramalan hasil amatan ke-i } \\
& n=\text { banyak data }
\end{aligned}
$$

Kriteria nilai MAPE ditunjukkan sebagai berikut (Billah et al., 2006):

Tabel 1. Kriteria nilai MAPE

\begin{tabular}{cc}
\hline Nilai MAPE & Kriteria \\
\hline$<10 \%$ & Sangat Baik \\
$10 \%-20 \%$ & Baik \\
$20 \%-50 \%$ & Cukup baik \\
$>50 \%$ & Buruk \\
\hline
\end{tabular}

\section{HASIL DAN PEMBAHASAN}

Pada penelitian ini digunakan data Indeks Pembangunan Manusia di Kabupaten Bojonegoro mulai tahun 2010-2020 menggunakan metode Double Exponential Smoothing dari Brown. Berdasarkan Gambar 1, terlihat bahwa nilai IPM Kabupaten Bojonegoro terus mengalami peningkatan setiap tahunnya, sehingga disimpulkan bahwa nilai IPM Kabupaten Bojonegoro berpola trend kenaikan.

Setelah mengetahui bahwa pola data IPM Kabupaten Bojonegoro merupakan data trend, selanjutnya dilakukan perhitungan menggunakan metode Double Exponential Smoothing dari Brown berdasarkan persamaan (1) sampai persamaan (5). Tabel 2 menunjukkan hasil perhitungan peramalan IPM Kabupaten Bojonegoro menggunakan metode double exponential smoothing dari Brown.

Tabel 2. Hasil perhitungan peramalan IPM Kabupaten Bojonegoro

\begin{tabular}{ccccccc}
\hline Tahun & Nilai IPM & $S_{t}^{f}$ & $S_{t}^{\prime \prime}$ & $a_{t}$ & $b_{t}$ & $f_{t+m}$ \\
\hline 2010 & 62.19 & 62.19 & 62.19 & 62.19 & 0.84 & - \\
2011 & 63.22 & 62.91 & 62.69 & 63.13 & 0.50 & 63.03 \\
2012 & 64.2 & 63.81 & 63.48 & 64.15 & 0.78 & 63.63 \\
2013 & 64.85 & 64.54 & 64.22 & 64.86 & 0.74 & 64.93 \\
2014 & 65.27 & 65.05 & 64.80 & 65.30 & 0.58 & 65.60 \\
\hline
\end{tabular}




\begin{tabular}{ccccccc}
\hline Tahun & Nilai IPM & $S_{t}^{f}$ & $S_{t}^{n f}$ & $a_{t}$ & $b_{t}$ & $f_{t+m}$ \\
\hline 2015 & 66.17 & 65.83 & 65.52 & 66.14 & 0.72 & 65.88 \\
2016 & 66.73 & 66.46 & 66.18 & 66.74 & 0.66 & 66.87 \\
2017 & 67.28 & 67.03 & 66.78 & 67.29 & 0.60 & 67.40 \\
2018 & 67.85 & 67.61 & 67.36 & 67.85 & 0.58 & 67.89 \\
2019 & 68.75 & 68.41 & 68.09 & 68.72 & 0.73 & 68.43 \\
2020 & 69.04 & 68.85 & 68.62 & 69.08 & 0.53 & 69.46 \\
2021 & - & - & - & - & - & 69.61 \\
2022 & - & - & - & - & - & 70.14 \\
2023 & - & - & - & - & - & 70.67 \\
\hline
\end{tabular}

Dalam mendapatkan hasil forecasting atau peramalan yang terbaik, maka perlu ditentukan nilai parameter a terbaik dengan kisaran 0 dan 1 berdasarkan proses trial and error, untuk memperoleh nilai MAPE terkecil digunakan persamaan (6). Tabel 3 menunjukan hasil perhitungan nilai parameter a terbaik.

Tabel 3. Nilai a terbaik berdasarkan MAPE terkecil

\begin{tabular}{cc}
\hline $\boldsymbol{\alpha}$ & MAPE \\
\hline 0.1 & $3.134 \%$ \\
0.2 & $1.624 \%$ \\
0.3 & $0.873 \%$ \\
0.4 & $0.536 \%$ \\
0.5 & $0.417 \%$ \\
0.6 & $0.386 \%$ \\
0.7 & $\mathbf{0 . 3 7 6 \%}$ \\
0.8 & $0.387 \%$ \\
0.9 & $0.387 \%$ \\
\hline
\end{tabular}

Berdasarkan Tabel 3 diperoleh nilai MAPE terkecil dengan nilai $a=0.7$ sebesar $0.376 \%$, dimana hasil MAPE tersebut masuk pada kriteria sangat baik. Setelah diperoleh nilai parameter a terbaik, selanjutnya dilakukan peramalan Indeks Pembangunan Manusia di Kabupaten Bojonegoro selama 3 Tahun yang akan datang menggunakan persamaan (5) berdasarkan nilai parameter terbaik yaitu $\alpha=0.7$. Perhitungan pada Tabel 2 sudah berdasarkan pada nilai $\alpha=0.7$.

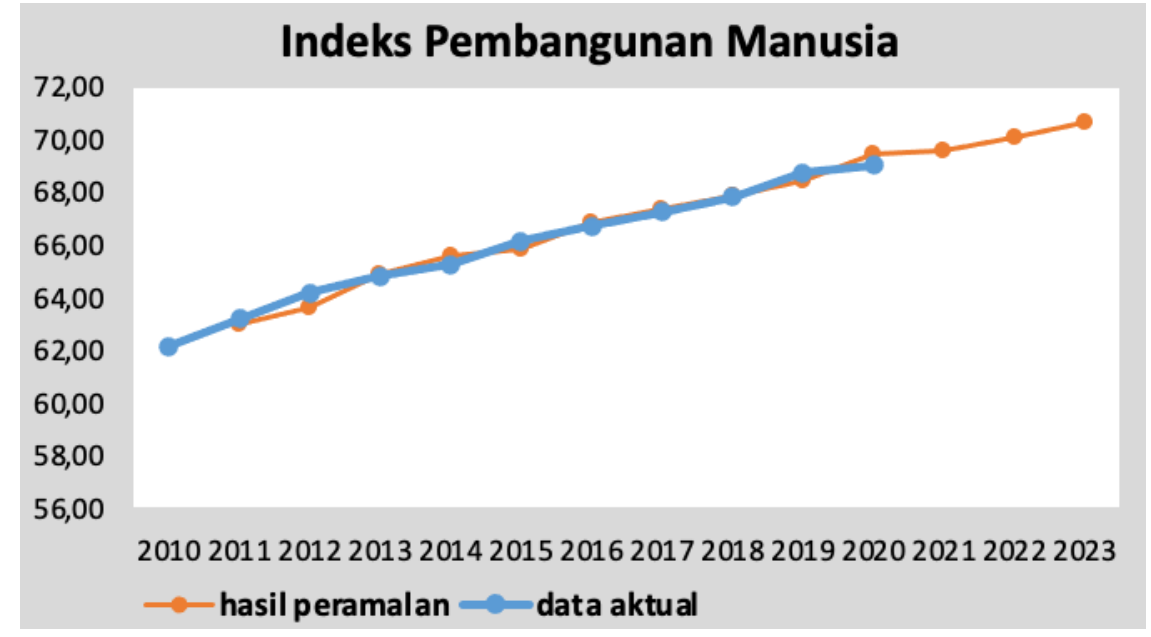

Gambar 2. Perbandingan hasil peramalan dengan data sebenarnya 
Berdasarkan Gambar 2 menunjukkan perbandingan hasil peramalan IPM Kabupaten Bojonegoro dengan data yang sebenarnya. Peramalan Indeks Pembangunan manusia (IPM) Kabupaten Bojonegoro untuk tahun 2021 sebesar 69.61, untuk tahun 2022 sebesar 70.14, dan sebesar 70.67 untuk tahun 2023. Hal ini menunjukkan bahwa IPM Kabupaten Bojonegoro untuk 3 tahun yang akan datang yaitu tahun 2021, 2022, dan 2023 menunjukkan kecenderungan pola garis data mengalami kenaikan, sehingga hasil IPM mengalami peningkatan setiap tahunnya. Dalam Rencana Pembangunan Jangka Menengah Daerah (RPJMD) Kabupaten Bojonegoro, Perkembangan capaian IPM di Kabupaten Bojonegoro dalam beberapa waktu terakhir menunjukkan pertumbuhan yang cukup signifikan, meskipun laju pertumbuhannya tidak melejit cepat, namun telah membuat peringkat IPM di Kabupaten Bojonegoro terus merangkak naik diantara Kabupaten lain di Provinsi Jawa Timur dan telah masuk dalam kategori sedang.

Berdasarkan Tabel 3 diperoleh nilai MAPE terkecil sebesar $0.376 \%$, dimana hasil tersebut lebih baik dibandingkan dengan penelitian sebelumnya pada peramalan Indeks Pembangunan Manusia di Provinsi Jawa Tengah yang menghasilkan nilai MAPE sebesar $0.4894 \%$ (Irawan \& Laksito, 2019).

\section{KESIMPULAN}

Berdasarkan perhitungan, analisis, dan pembahasan yang telah dilakukan, didapatkan kesimpulan bahwa perhitungan peramalan IPM di Kabupaten Bojonegoro menggunakan metode Double Exponential Smoothing dari Brown menghasilkan nilai parameter a terbaik yaitu 0.7 dengan nilai MAPE sebesar $0.376 \%$ yang masuk ke dalam kriteria sangat baik, sehingga diperoleh hasil peramalan (forecasting) IPM Kabupaten Bojonegoro untuk 3 tahun kedepan yaitu untuk tahun 2021 sebesar 69.61, untuk tahun 2022 sebesar 70.14, dan sebesar 70.67 untuk tahun 2023, nilai tersebut masuk ke dalam kategori IPM sedang.

\section{REKOMENDASI}

Berdasarkan hasil pembahasan di atas, mengenai peramalan data runtun waktu (time series) Indeks Pembangunan Manusia (IPM) di Kabupaten Bojonegoro yang berpola data trend kenaikan dengan menggunakan metode Double Exponential Smoothing dari Brown yang menunjukkan nilai kesalahan peramalan sangat kecil yaitu nilai MAPE sebesar $0.376 \%$, meskipun data yang digunakan sangat terbatas. Oleh karena itu, untuk penelitian selanjutnya penulis menyarankan dalam melakukan peramalan menggunakan metode double exponential smoothing dari Brown untuk lebih dikembangkan dengan menggunakan data yang lebih banyak lagi, dan mencoba peramalan menggunakan metode-metode lain yang sesuai dengan karakteristik dan pola data runtun waktu.

\section{UCAPAN TERIMAKASIH}

Peneliti mengucapkan terima kasih kepada UIN Sunan Ampel yang telah mendukung terhadap pelaksanaan penalitian ini.

\section{DAFTAR PUSTAKA}

Airlangga, G., Rachmat, A., \& Lapihu, D. (2019). Comparison of exponential smoothing and neural network method to forecast rice production in Indonesia. Telkomnika (Telecommunication Computing Electronics and Control), 17(3), 1367-1375. https://doi.org/10.12928/TELKOMNIKA.V17I3.11768

Bappeda, B. (2020). Penyusunan IPM Kecamatan dan Kabupaten Bojonegoro 2020. Badan Perencanaan Pembangunan Daerah Kabupaten Bojonegoro. https://bappeda.bojonegorokab.go.id 
Billah, B., King, M. L., Snyder, R. D., \& Koehler, A. B. (2006). Exponential smoothing model selection for forecasting. International Journal of Forecasting, 22(2), 239-247. https://doi.org/10.1016/j.ijforecast.2005.08.002

Bojonegoro, B. (2013). Rencana Pembangunan Jangka Panjang Daerah (RPJPD) Kabupaten Bojonegoro 2005-2025. Badan Perencanaan Pembangunan Daerah Kabupaten Bojonegoro. https://bappeda.bojonegorokab.go.id

BPS, J. T. (2020). Jawa Timur dalam angka 2020. BPS Jawa Timur. https://jatim.bps.go.id

Dewi, N. L. S. D., \& Sutrisna, I. ketut. (2012). Pengaruh komponen indeks pembangunan manusia terhadap pertumbuhan ekonomi Provinsi Bali. E-Jurnal Ekonomi Pembangunan Universitas Udayana, 3(3), 106-114.

Fauziah, F. N., \& Gunaryati, A. (2017). Comparison forecasting with double exponential smoothing and artificial neural network to predict the price of sugar. 1-8. https://doi.org/10.5013/lJSSST.a.18.04.13

Gyo, M., \& Kim, S. (2013). Efficient jitter compensation using double exponential smoothing. Information Sciences, 227, 83-89. https://doi.org/10.1016/j.ins.2012.12.008

Hansun, S. (2016). A new approach of brown's double exponential smoothing method in time series analysis. Balkan Journal of Electrical and Computer Engineering, 4(2), 75-78. https://doi.org/10.17694/bajece.14351

Hyndman, R. J., Koehler, A. B., Snyder, R. D., \& Grose, S. (2002). A state space framework for automatic forecasting using exponential smoothing methods. International Journal of Forecasting, 18, 439-454. www.elsevier.com/ locate / ijforecast

Irawan, R. Y., \& Laksito, W. (2019). Penerapan metode double exponential smoothing untuk peramalan tingkat indeks pembangunan manusia. Journal TIKomSIN, 7(2), 18-28. https://doi.org/https://doi.org/10.30646/tikomsin.v7i2.437

Ismail, Z., \& Yeng, F. F. (2011). Genetic algorithm for parameter estimation in double exponential smoothing. Australian Journal of Basic and Applied Sciences, 5(7), 1174-1180.

Jahring, \& Pradani, A. P. (2016). Forecasting with double exponential smoothing brown method. Journal of Math Science, 1(2), 35-39. http://usnsj.com/index.php/JMS/article/view/JMS006

Jr, J. J. L. (2003). Double Exponential smoothing: an alternative to kalman filter-based predictive tracking. International Immersive Projection Technologies Workshop.

Liantoni, F., \& Agusti, A. (2018). Forecasting bitcoin using double exponential smoothing method based on mean absolute percentage error. International Journal on Informatics Visualization, $4(2), 91-95$.

Lukman, M., \& Tanan, B. (2021). Time Series modeling by using exponential smoothing technique for river flow discharge forecasting (case study: cabenge, walanae, and cenranae rivers system). IOP Conference Series: Materials Science and Engineering, 1088(1), 012100. https://doi.org/10.1088/1757-899x/1088/1/012100 
Mirza, D. S. (2012). Pengaruh kemiskinan, pertumbuhan ekonomi, dan belanja modal terhadap indeks pembangunan manusia di jawa tengah tahun 2006-2009. Economics Development Analysis Journal, 1(1). http://journal.unnes.ac.id/sju/index.php/edaj

Muchayan, A. (2019). Comparison of holt and brown's double exponential smoothing methods in the forecast of moving price for mutual funds. Journal of Applied Science, Engineering, Technology, and Education, 1(2), 183-192. https://doi.org/https://doi.org/10.35877/454RI.asci1167

Ouedraogo, N. S. (2013). Energy consumption and human development: evidence from a panel cointegration and error correction model. Energy, 63(1A), 28-41. https://doi.org/10.1016/j.energy.2013.09.067

Rana, M., \& Koprinska, I. (2016). Neurocomputing forecasting electricity load with advanced wavelet neural networks. Neurocomputing, 182, 118-132. https://doi.org/10.1016/j.neucom.2015.12.004

Sagar, A. D., \& Najam, A. (1998). The human development index: a critical review. Ecological Economics, Elsevier, 25 (3), 249-264.

Saputra, N. D., Aziz, A., \& Harjito, B. (2017). Parameter optimization of brown's and holt's double exponential smoothing using golden section method for predicting Indonesian Crude Oil Price (ICP). Proceedings-2016 3rd International Conference on Information Technology, Computer, and Electrical Engineering, ICITACEE 2016, 356-360. https://doi.org/10.1109/ICITACEE.2016.7892471

Setiawan, M. B., \& Hakim, A. (2008). Indeks pembangunan manusia indonesia. Jurnal Ekonomia, $9(1), 18-26$.

Syafwan, H., Syafwan, M., Syafwan, E., \& Hadi, A. F. (2021). Forecasting unemployment in north sumatra using double exponential smoothing method. J. Phys. Conf, 1783 (1), https://doi.org/10.1088/1742-6596/1783/1/012008

Tang, J., Xu, G., Wang, Y., Wang, H., Zhang, S., \& Liu, F. (2013). Traffic flow prediction based on hybrid model using double exponential smoothing and support vector machine. Proceedings of the 16th International IEEE Annual Conference on Intelligent Transportation Systems (ITSC 2013), 130-135.

Ubeyli, E. D. (2005). Adaptive neuro-fuzzy inference system for classification of eeg signals using wavelet coefficients. Journal of Neuroscience Methods, 148(2), 113-121 https://doi.org/10.1016/j.jneumeth.2005.04.013

Wang, J., Wang, J., Zhang, Z., \& Guo, S. (2011). Expert systems with applications forecasting stock indices with back propagation neural network. Expert Systems With Applications, 38(11), 14346-14355. https://doi.org/10.1016/j.eswa.2011.04.222

Wang, J., Wang, J., Zhang, Z., \& Guo, S. (2012). Stock index forecasting based on a hybrid model. Omega, 40(6), 758-766. https://doi.org/10.1016/j.omega.2011.07.008 
Winarti, A. (2014). Analisis pengaruh pengeluaran pemerintah bidang pendidikan, kemiskinan, dan pdb terhadap indeks pembangunan manusia di indonesia periode 1992-2012. Skripsi. Fakultas Ekonomika dan Bisnis, Universitas Diponegoro, Semarang.

Zhang, G. P. (2003). Time series forecasting using a hybrid arima and neural network model. Neurocomputing, 50, 159-175. www.elsevier.com/locate/neucom 